\section{Kadınlarda kalsiyum ve kalsiyum emilimine yardımcı olan diğer besin öğeleri tüketiminin değerlendirilmesi}

* Sorumlu Yazar / Corresponding Author: Wida Simzari

Kapadokya Üniversitesi Sağlık Bilimleri Meslek Yüksekokulu Beslenme ve Diyetetik Programı Mustafapaşa 50420 Ürgüp, Nevşehir / Türkiye E-posta: wida.simzari@kapadokya.edu.tr

\section{Wida Simzari ${ }^{\prime *}$, H. Tanju Besler ${ }^{2}$, Sakineh Nouri Saeidlou ${ }^{3}$, Yener Bektaş ${ }^{4} \oplus$}

${ }^{1}$ Dr. Öğr. Üyesi | Kapadokya Üniversitesi, Beslenme ve Diyetetik Bölümü, Nevşehir - Türkiye ${ }^{2}$ Prof. Dr. | İstanbul Kent Üniversitesi, Beslenme ve Diyetetik Bölümü, İstanbul - Türkiye

${ }^{3}$ Doç. Dr. | Urmia University of Medical Sciences, Food and Beverages Safety Research Centre, Urmia - İran ${ }^{4}$ Prof. Dr. | Nevşehir Hacı Bektaş Veli Üniversitesi, Arkeoloji Bölümü, Nevşehir - Türkiye

\section{Öz}

Beslenme durumu bireyin besin öğelerine olan fizyolojik gereksiniminin karşılanma düzeyini yansıtır. Besin öğelerinden olan kalsiyumun yeterli alımı tüm yaş gruplarındaki bireyler için önemlidir. Bununla birlikte kadınların fizyolojik yapıları gereği bu besin öğesini yeterli seviyede almaları daha fazla önem taşımaktadır. Kesitsel yöntem izlenerek yapılan bu çalışma İran'ın Erdebil ilinde yaşayan 18-30 yaş arasındaki 400 kadın üzerinde yürütülmüștür. Katılımcıların sosyo-ekonomik durumlarını ve beslenme alıskanlıklarını içeren veriler anket formu uygulanarak toplanmıştır. Besin tüketim durumunun saptanmasında “24 saat besin tüketimi yöntemi” kullanılmıștır. Tüketilen günlük enerji ve besin öğeleri, diyetle önerilen günlük alım (DRI) miktarlarına göre değerlendirilmiştir. Elde edilen verilerin istatistiki analizinde SPSS 16.0 programı kullanılmıştır. Kentte yaşayan kadınların günlük aldıkları enerj ve protein miktarları kırsalda yaşayanlardan daha yüksek ve aralarındaki fark da istatistiki olarak anlamlı bulunmuştur $(p<0,001),(p<0,05)$. Kentte ve kırsalda ortalama protein alımı DRI değerinin (46 g/gün) üzerinde bulunmuştur. Öte yandan kadınların enerji, magnezyum, çinko, kalsiyum alımları ise DRI değerinin altında saptanmıştır. Kentte ve kırsalda yaşayan kadınların kalsiyum alımları yönünden aralarındaki farklılık $(p<0,001)$ ile lise mezunu kadınların ortalama kalsiyum alımları yönünden aralarındaki farklılık istatistiki olarak anlamlı bulunmuştur $(\mathrm{p}<0,001)$. Sonuç olarak bu çalışma hem kentte hem de kırsalda yaşayan kadınların kalsiyum alım miktarlarının önerilen değerlerden daha düşük olduğunu göstermektedir. Ek olarak kırsalda yaşayan kadınlar kentte yaşayan kadınlara göre daha düşük miktarda kalsiyum alım değerine sahiptir ve bu fark anlamlıdır.

Anahtar Sözcükler: Kadın, kalsiyum alımı, İran, kent, kırsal

\section{Giriş}

Yaş ile birlikte değişikliğe uğrayan kemik mineral yoğunluğunda genç yaşlarda sürekli bir artış gözlenirken bu artış osteoblastik sürecin inhibe olduğu 30'lu yaşlardan itibaren azalarak devam eder. Temel kemik yapıcı besin öğesi olan kalsiyumun doğru miktarda alımı
Evaluation of the consumption of calcium and calciumabsorbant nutritional elements in women

\section{Abstract}

Nutritional status reflects the level of satisfaction of a person's physiological needs for nutrients. Adequate consumption of calcium, which is one of the nutrients, is important for individuals of all age groups. However, it is more important for women to take this nutrient at a sufficient level due to their physiological structure. The study was a cross-sectional study conducted on 400 women aged 18-30 years in Ardabil district, Iran. Data were collected using socio-economic and food habits questionnaires. "24-hour recall" was used to determine the food intake status. The daily energy and nutrients consumed were evaluated according to the dietary recommended intake (DRI). The obtained data were evaluated using the SPSS 16.0 statistical computer program. Results showed that the energy and protein intake in urban areas was higher than in rural areas, and these differences were significant respectively $(p<0.001$, $p<0.05)$. The mean protein intake in urban and rural areas was above the DRI value $(46 \mathrm{~g} / \mathrm{d}$ ). Energy, magnesium, zinc and calcium intakes were determined below the DRI value. The difference between women living in urban and rural areas in terms of calcium intake is significant $(p<0.001)$. The difference between the average calcium intake of high school graduate women living in urban and rural areas is significant $(p<0.001)$. This study showed that the amount of calcium intake of women living in urban and rural areas was lower than the recommendations. In addition, calcium intake in rural areas was less than in urban areas, and this difference was significant.

Key Words: Women, calcium intake, Iran, urban, rural

kemiğin genç yaştaki büyüme oranının ve daha sonraki y1llarda iskelet sisteminin uygun mineralizasyonunun korunmasına destek olmaktadır. Bu süreç aynı zamanda kalsiyum emilimini etkileyen diğer besin öğelerinin (D vitamini, çinko, magnezyum, fosfor) yeterli alımı ve fiziksel aktivite düzeyi gibi faktörlere de bağlıdır. Bu 
besin öğeleri arasında bulunan D vitamini iskelet dâhil olmak üzere fizyolojik fonksiyonlarda çok önemli bir rol oynar ve nöronların hayatta kalması için hayatî önem taş1r (Wrzosek vd., 2019). Bu vitamin nöral progenöral hücrelerin proliferasyon ve farklılaşması için gereklidir. Dolayısıyla doğrudan veya dolaylı olarak D vitamini eksikliği depresyon gelişimini veya depresyonun ilerlemesini etkileyebilmektedir (Geng vd., 2019). Yine kalsiyum emilimini kolaylaştırıcı etmenlerden kalsiyum fosfor oranının 1 olması yanında sitrik asit, lizin ve arginin gibi amino asitlerin de diyette yeteri kadar alınması önerilmektedir. Ek olarak diyette fitik ve oksalik asitler ile magnezyumun fazla alımı kalsiyum-fosfor dengesini bozmakta ve kalsiyum emilimini olumsuz yönde etkilemektedir (Robinson, 2020).

Toplam vücut ağırlı̆̆ının \%1,5-2'sini oluşturan kalsiyum, insan vücudunda en fazla bulunan mineraldir. Kalsiyumun \%98'i iskelette depolanır, geri kalan k1sm1 dişlerde, yumuşak dokularda, plazmada ve ekstra sellüler sivilarda bulunmaktadir (Weaver vd., 2019). Kalsiyum iskelet yapisinda hidroksi apatit $\left[\mathrm{Ca}_{10}\left(\mathrm{PO}_{4}\right)_{6}(\mathrm{OH})_{2}\right]$ kristal formundadır. Bu yapının öncüsü olarak adlandırılabilen amorfoz trikalsiyum fosfat $\left[\mathrm{Ca}_{8}\left(\mathrm{PO}_{4}\right)_{2}\right]$ formu da vardir (Institute of Medicine, 2011). Bu, organik kollajen matriksini saran kristal kalsiyum fosfat yapısıdır. Magnezyum ve çinko gibi minerallerde bu yap1 içinde yer alırlar. Buna göre kemiğin \%70’i minerallerden, \%30’u da organik yapıdaki protein, nükleoprotein ve birleşik proteinlerden oluşur (Pugliese vd., 1998). Kolay değişen kalsiyum uzun kemiklerin uç kısımlarında kristal yapıdadir. Buna trabule denilmektedir ve gebelik, büyüme ve emzirme sırasında artan gereksinimi karşılamak için kolayca mobilize olur (Robinson, 2020). Uzun süre yetersiz kalsiyum alımında bu bölümün kalsiyum içeriği azaldığından dayanıklı kısımda da çözünme olur. İnsan vücudunun normal fonksiyonu için diyette kalsiyum alımı elzemdir. Kalsiyum iskelet sisteminin önemli bir bileşeni olmasının yanı sıra hücre organellerinin yapısının korunmasına, hücre içi ve hücre dişı sıv1 dengesinin sağlanmasına da yardımcı olur (Baysal, 2017).

Kalsiyum, endojen ve eksojen birtakım süreçlerin etkinliğinden de sorumludur. Endojen faktörler arasında gebelik, emzirme, menopoz, yaşlilik, hormonlar, kalsiyum metabolizmasıyla ilişkili büyüme faktörleri, kalsiyum emilimini sınırlandıran hastalıklar ve bağırsak mikrobiyotası gibi faktörler sayılabilir. Vücuttaki kalsiyumun kaynağı genetik olarak koşullandırılmış ve kişiye özel olsa da kalitatif ve kantitatif bileşimi eksojen faktörler tarafından da değiştirilebilir. Bu eksojen faktörler arasında belirli besinler ve farmakolojik tedaviyle diyet değişiklikleri ile kültüre özgü beslenme alışkanlıkları sayılabilir (Wawrzyniak vd., 2021).

Literatürde farklı coğrafyalarda yaşayan insanlar üzerinde besin öğelerinin yeterli/yetersiz alımı ile ilgili birçok araştırma bulunmakla birlikte kendi içerisinde farklı yeme örüntülerine sahip İran'da bu konudaki araştırmaların sayısının sınırlı olduğu ve var olan çeşitliliğin anlaşılabilmesi için bölgesel olarak yürütülmüş çalışmalara ihtiyaç duyulduğu gözlenmiştir. Bu noktadan hareketle gerçekleştirilmiş olan bu araştırmada İan'ın Erdebil ilinin kent ve kırsalında yaşayan 18-30 yaş arasındaki kadınlar örneklem grubu olarak seçilmiş ve kadınların diyetlerinde tükettikleri kalsiyum miktarı ve kalsiyum emilimine yardımcı besin öğeleri incelenerek beslenme durumlarının ortaya konulması amaçlanmıştır.

\section{Gereç ve yöntem}

Bu çalışma, Iran'ın kuzeyinde yer alan Erdebil ilinde yaşayan ve araştırmaya katılmayı gönüllü olarak kabul eden, emziren ya da gebe olmayan 18-30 yaş aras1 400 yetişkin kadın üzerinde gerçekleştirilmiştir. Örneklem grubunda yer alan kadınların 100’ü Erdebil kırsalında, 300’ü de şehir merkezinde yaşamaktadır. Erdebil nüfusu, bir milyon üç yüz bin civarında olup (İran İstatistik Kurumu, 2010), hem kültürel hem de beslenme alışkanlıkları açısından Türkiye ile benzerlikler göstermektedir. Araştırmada katılımcıların eğitim durumları, meslekleri, ek kalsiyum ve D vitamini kullanıp kullanmadıklarına ilişkin sorular ile besin tüketim durumlarının saptanmasına ilişkin soruların yer aldığı bir anket uygulanmıştır. Bu anket içerisinde bireylerin besin tüketim durumunun saptanmasinda "24 Saat Besin Tüketimi Formu" kullanılmıştır. Besin tüketim durumunun saptanmasında yararlanılan "bireysel besin tüketim yöntemi”, bireyin bir gün boyunca aldığ1 besinlerin miktarlarını saptayıp, enerji ve besin öğelerinin hesaplanması esasına dayanmaktadır. Birbirini izleyen üç gün süreyle (biri tatil, ikisi çalışma günü) bireylerin besin tüketimleri alınmıştır (Pekcan, 2018).

Besin tüketim analizi için Food Proccessor adlı bilgisayar programindan yararlanılarak bireylerin tükettikleri besinlerin ortalama günlük enerji ve besin öğeleri miktarları tespit edilmiştir (USA, Canadian Standard Food Analyze, 1998). Ayrıca tüketilen günlük enerji ve besin öğeleri diyette önerilen günlük alım (DRI士\%33) miktarlarına (<\%67 yetersiz, \%67-133 yeterli, >\%133 fazla) göre değerlendirilmiştir (Institute of Medicine, 1997, 2001; Trumbo vd., 2002). Elde edilen verilerin istatistik analizlerinde SPSS 16.0 programı kullanılmıştır. Değişkenler için iki bağımsız grup karşılaştırmasında Student $t$-testi kullanılmıştır. Değerler ortalama \pm standart sapma (SS) olarak verilmiştir.

\section{Bulgular}

Araştırma kapsamına alınan kadınların \%75,0’i kentte, $\% 25,0$ ’i kırsalda yaşamaktadırlar. Kadınların yaş ortalaması

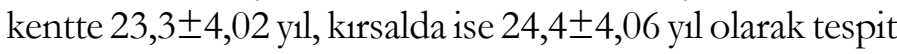
edilmiştir. Eğitim sürelerinin ortalaması kentte 12,6 $\pm 2,5$ y1l, kırsalda ise 10,3 $\pm 3,4$ yildır. Kentteki kadınların 
Tablo 1. Katılimcılarn tanımlayıcı eğitim ve meslek bilgileri

\begin{tabular}{lccc}
\hline \multicolumn{1}{c}{ Ĕ̈itim Düzeyi ve Meslek } & Kent (n=300) & Kırsal (n=100) & Toplam (n=400) \\
\hline Eğitim düzeyi & & & 10,3 \\
$\quad$ İlkokul & 4,3 & 28,0 & 74,0 \\
Lise & 76,0 & 68,0 & 15,2 \\
Üniversite & 19,0 & 4,0 & 0,5 \\
Yüksek lisans veya doktora & 0,7 & - & \\
Meslek & & & 29,5 \\
Ev hanımı & 20,7 & 56,0 & 5,7 \\
Memur & 6,0 & 5,0 & 48,0 \\
Üniversite öğrencisi & 54,3 & 29,0 & 9,3 \\
Hemşire & 11,7 & 2,0 & 7,5 \\
Diğer & 7,3 & 8,0 & \\
\hline
\end{tabular}

Not: Verilen değerler yüzdelik oranlarıdır

Tablo 2. Bireylerin ek D vitamini ve kalsiyum kullanm oranlar

\begin{tabular}{|c|c|c|c|}
\hline Vitamin ve mineraller & Kent $(n=300)$ & Kirsal $(n=100)$ & Toplam $(n=400)$ \\
\hline $\mathrm{D}$ vitamini & 2,0 & - & 2,0 \\
\hline Kalsiyum & 2,0 & - & 2,0 \\
\hline
\end{tabular}

Not: Verilen değerler yüzdelik oranlarıdır

\%4,3'ü ilkokul, \%76,0's1 lise, \%19,0’u üniversite, \%0,7'si yüksek lisans veya doktora mezunu, kırsaldaki kadınların ise \%28,0’i ilkokul, \%68,0’i lise ve \%4,0’ü üniversite mezunudurlar. Bireylerin mesleklerine göre dağılımları incelendiğinde; kentte yaşayanların \%20,7'si, kırsalda yaşayanların ise \%56,0'sı ev hanımıdır. Kenttekilerin \%54,3’ü, kırsaldakilerin \%29,0’u üniversite öğrencisi iken, kentte yaşayanların \%11,7'si, kırsalda yaşayanların \%2,0'si hemşire, kenttekilerin \%6,0's1 ve kırsaldakilerin \%5,0'i devlet memurudur. Kentte $(\% 7,3)$ ve kırsalda $(\% 8,0)$ diğer meslekler öğretmen, doktor, kuaför, sinema ve tiyatro oyuncusu ve fabrikada işçi olarak belirlenmiştir (Tablo 1).

Katılımciların ek D vitamini ve kalsiyum kullanım durumuna göre dağılımları incelendiğinde, kentte ve kırsalda kullananların oranlarının benzer olduğu saptanmiştır (Tablo 2).

Çalışmaya katılan bireylerin beslenme durumlarını değerlendirildiğinde kadınların günlük enerji ve besin öğesi alımına ilişkin tanımlayıcı istatistikler Tablo 3'te verilmiştir. Araştırma kapsamına alınan kadınların ortalama enerji alımları, kentte ve kirsalda sirasiyla $2094 \pm 704,8$ ve $1937,9 \pm 632,7$ kkal'dir. Protein için sirasiyla $87 \pm 40,9$ ve $74,1 \pm 22,7 \mathrm{~g}$, fosfor $1110 \pm 561,5$ ve $1064 \pm 570,6 \mathrm{mg}$, magnezyum $148 \pm 92,9$ ve $157 \pm 84,5$ ve kalsiyum $818,9 \pm 532,3$ ve $631,8 \pm 371,9$ mg'dır. Kentte ve kırsalda yaşayan kadınların enerji, protein alımları açısından aralarındaki farklılık önemli bulunmuştur $(p<0,05)$. Kentte ve kirsalda ortalama protein, fosfor alımları önerilen DRI değerlerinin üzerindedir. Enerji, magnezyum, kalsiyum, alımı kent ve kırsalda ortalama
DRI değerlerinin altındadır. Kentte ve kırsalda yaşayan kadınlar mineral alımları açısından değerlendirildiğinde kalsiyum alımları yönünden aralarındaki farklılık önemlidir $(p<0,05)$. Kentte ve kırsalda yaşayan kadınların ortalama kalsiyum tüketimleri sırayla DRI değerinin \%81,8'i ve \%63,0'ü iken ortalama magnezyum alımı \%47,7'sine ve \%50,6'sina, çinko \%62,0'sine ve $\% 67,9$ 'una, fosfor alımı \%158,5'ine ve \%152,0'sine, protein alımı ise \%189,0'una ve \%161,0'ine denk gelmektedir (Tablo 3).

Kadınların enerji ve besin öğesi alımlarının yeterlik düzeyi Tablo 4'te verilmiştir. Kentte ve kırsalda yaşayan kadınların protein, fosfor alımları DRI'ya göre değerlendirildiğinde, günlük alım düzeylerinde fazla olanların oranın yetersiz ve yeterli olanlara göre daha yüksek olduğu ve kentte ise kırsala oranla daha yüksek olduğu tespit edilmiştir. Yine DRI'ya göre kalsiyum, çinko ve magnezyum açısından kadınların büyük çoğunluğunun hem kentte hem de kırsalda yetersiz alıma sahip olduğu bulunmuştur (Tablo 4).

Bireylerin eğitim durumuna göre kalsiyum alımına ilişkin değerler Tablo 5'te gösterilmektedir. Ortalama kalsiyum alımı açısından kentte ve kırsalda yaşayan lise mezunu kadınlar arasında istatistiki olarak anlamlı bir farklılık bulunmuştur $(\mathrm{p}<0,001)$. Kentteki lise mezunu kadinlarda ortalama kalsiyum alımları $826,5 \pm 544,7 \mathrm{mg}$ kırsalda ise $648,7 \pm 394,3 \mathrm{mg}$ 'dır. Kentte yaşayan yüksek lisans veya doktora mezunu kadinların ortalama kalsiyum alımı 1065 $\pm 394,6$ mg'dir (Tablo 5). 
Simzari vd.| Antropoloji (42) (2021), 27-35

Tablo 3. Kadınlarn günlük enerji ve besin öğesi almmna ilişkin değerler

\begin{tabular}{|c|c|c|c|c|c|c|c|c|}
\hline Enerji ve besin öğeleri & Ort. (SS) & $\mathrm{S} \overline{\mathbf{x}}$ & $\begin{array}{l}\text { Alt } \\
\text { sinir }\end{array}$ & $\begin{array}{l}\text { Üst } \\
\text { sinir }\end{array}$ & $\begin{array}{c}\text { DRI } \\
\text { düzeyleri }\end{array}$ & DRI $\%$ & $t$ & $p$ \\
\hline \multicolumn{9}{|l|}{ Enerji (kkal) } \\
\hline Kent & $2094,0(704,8)$ & 40,70 & 689 & 4494 & \multirow{2}{*}{2403 kkal } & 87,0 & \multirow{2}{*}{2,07} & \multirow{2}{*}{$0,03^{*}$} \\
\hline Kırsal & $1937,9(632,7)$ & 63,27 & 923 & 4016 & & 78,0 & & \\
\hline \multicolumn{9}{|l|}{ Protein (\%) } \\
\hline Kent & $16,1(3,7)$ & 0,21 & 7 & 37 & \multirow{2}{*}{$\% 10-35$} & - & \multirow{2}{*}{1,24} & \multirow{2}{*}{0,24} \\
\hline Kirsal & $15,6(3,0)$ & 0,30 & 8 & 24 & & - & & \\
\hline \multicolumn{9}{|l|}{ Protein $(g)$} \\
\hline Kent & $87,0(40,9)$ & 2,39 & 19,1 & 411 & \multirow{2}{*}{$46 \mathrm{~g} / \mathrm{gün}$} & 189,0 & \multirow{2}{*}{4,01} & \multirow{2}{*}{$<0,001^{* * *}$} \\
\hline Kırsal & $74,1(22,7)$ & 2,27 & 27,3 & 148 & & 161,0 & & \\
\hline \multicolumn{9}{|l|}{ Kalsiym (mg) } \\
\hline Kent & $818,9(532,3)$ & 30,73 & 122 & 3657 & \multirow{2}{*}{1000 mg/gün } & 81,8 & \multirow{2}{*}{3,87} & \multirow{2}{*}{$<0,001 * * *$} \\
\hline Kirsal & $631,8(371,9)$ & 37,18 & 120 & 2136 & & 63,0 & & \\
\hline \multicolumn{9}{|l|}{ Fosfor (mg) } \\
\hline Kent & $1110,0(561,5)$ & 32,41 & 112 & 4987 & \multirow{2}{*}{700 mg/gün } & 158,5 & \multirow{2}{*}{0,71} & \multirow{2}{*}{0,64} \\
\hline Kirsal & $1064,0(570,6)$ & 57,06 & 184 & 3380 & & 152,0 & & \\
\hline \multicolumn{9}{|l|}{$\mathrm{Ca} / \mathbf{P}$} \\
\hline Kent & $0,8(0,33)$ & 0,02 & 0,1 & 2,1 & \multirow{2}{*}{$1 / 1$} & - & \multirow{2}{*}{3,01} & \multirow{2}{*}{0,68} \\
\hline Kırsal & $0,6(0,32)$ & 0,03 & 0,1 & 1,8 & & - & & \\
\hline \multicolumn{9}{|l|}{ Magnezyum (mg) } \\
\hline Kent & $148(92,9)$ & 5,4 & 17,2 & 738 & \multirow{2}{*}{310 mg/gün } & 47,7 & \multirow{2}{*}{$-0,86$} & \multirow{2}{*}{0,97} \\
\hline Kırsal & $157(84,5)$ & 8,4 & 44,2 & 478 & & 50,6 & & \\
\hline \multicolumn{9}{|l|}{ Çinko (mg) } \\
\hline Kent & $5,0(3,8)$ & 0,22 & 0,0 & 48,5 & \multirow{2}{*}{$8 \mathrm{mg} /$ gün } & 62,0 & \multirow{2}{*}{$-1,09$} & \multirow{2}{*}{0,91} \\
\hline Kırsal & $5,4(2,8)$ & 0,28 & 1,0 & 13,6 & & 67,9 & & \\
\hline
\end{tabular}

Not: Ort. (SS) = Ortalama (Standart sapma), $\mathrm{S} \overline{\mathrm{x}}=$ Standart hata, $t=$ test değeri, $p=$ anlamlılık değeri $* p<0,05 * * p<0,01 * * * p<0,001$

\section{Tartışma}

Dünyanın farklı bölgelerinde yaşayan insanlar arasında kültürel ve sosyal yapıda gözlenen çeşitlilik ile besinlere ulaşılabilirlik düzeyi gibi faktörler, bu insanların diyetlerinde kalsiyum alım miktarlarını da etkilemektedir (Hemmingway vd., 2018). Örneğin sütün nadiren tüketildiği Afrika kıtasında Sahra'nın güneyinde kalan alanlarda kalsiyum alımı kişi başına 200-300 mg/gün iken sütün düzenli tüketildiği İskandinav ülkelerinde kişi başına 1000-1500 mg/gün saptanmıştır. Buna benzer bir farklılık toplum içinde de gözlenebilir. Kalsiyum açısından zengin kaynakları tüketen kişilerde kalsiyum alımı bu kaynaklardan az veya hiç tüketmeyenlere göre daha yüksek miktarda saptanmaktadır. Bu farklılıklar vücudun mineral yapısında değişimlere ve sağlık sorunlarına yol açabilmektedir. Bugün bodurluk gelişmekte olan ülkelerde çocukların yaklaşı üçte biri ile küresel bir halk sağlık sorunu olmaya devam etmektedir. Ayrıca düşük kemik mineral yoğunluğu ile ilişkili kırıkların çocuklarda, ergenlerde ve osteoporozlu yaşlı erişkinlerde önemli bir sağlık sorunu olduğu bilinmektedir (Prentice, 2007).
Uluslararas1 Osteoporoz Vakfi'nın (IOF) 2017 y1lında gerçekleştirmiş olduğu araştırmaya göre Asya'daki birçok ülkede ortalama kalsiyum alımının günde 500 mg'den az olduğu, Afrika ve Güney Amerika'daki ülkelerde ise çoğunlukla günde yaklaşık 400 ile 700 mg arasında olduğu tespit edilmiştir. Sadece Kuzey Avrupa ülkelerinde kalsiyum alımının günde 1000 mg'nin üzerinde olduğu saptanmıştır. Ortalama kalsiyum alımı genellikle kadınlarda erkeklerden daha düşük olduğu bilinmekle birlikte toplumlar arasinda yaşa, cinsiyete ve sosyoekonomik düzeye göre kalsiyum alımına ilişkin net örüntüler henüz belirlenmemiştir (Balk vd., 2017).

Kalsiyum alımı yetersiz olan bireylerde ek kalsiyum desteği önemli bir role sahiptir. Bireyler diyetle aldıkları kalsiyumdan daha fazlasinı ek kalsiyum takviyesi olarak alabilmektedirler. Örneğin Amerika Birleşik Devletleri'nde osteoporozu önlemek ve tedavi etmek düşüncesi ile erkeklerin \%50'si ve kadınların \%65'i düzenli olarak kalsiyum takviyesi kullanmaktadırlar (Tisdale vd., 2019). Literatürde bazı araştırmalarda 
Tablo 4. Kadınlarn enerji ve besin ögesi almmlarnm yeterlilik düzeyi

\begin{tabular}{|c|c|c|c|}
\hline Enerji ve besin öğeleri (\%) & Yetersiz $(<\% 66)$ & Yeterli (\%67-133) & Fazla $(>\% 133)$ \\
\hline \multicolumn{4}{|l|}{ Enerji } \\
\hline Kent & 14,4 & 71,6 & 14,0 \\
\hline Kursal & 16,0 & 74,0 & 10,0 \\
\hline \multicolumn{4}{|l|}{ Protein } \\
\hline Kent & 2,3 & 24,0 & 73,7 \\
\hline Kirsal & 2,0 & 27,0 & 71,0 \\
\hline \multicolumn{4}{|l|}{ Kalsiym } \\
\hline Kent & 50,3 & 35,4 & 14,3 \\
\hline Kırsal & 63,0 & 31,0 & 6,0 \\
\hline \multicolumn{4}{|l|}{ Fosfor } \\
\hline Kent & 7,0 & 33,7 & 59,3 \\
\hline Kirsal & 9,0 & 40,0 & 51,0 \\
\hline \multicolumn{4}{|l|}{ Magnezyum } \\
\hline Kent & 83,7 & 13,7 & 2,6 \\
\hline Kirsal & 78,0 & 20,0 & 2,0 \\
\hline \multicolumn{4}{|l|}{ Çinko } \\
\hline Kent & 69,0 & 26,3 & 4,7 \\
\hline Kırsal & 62,0 & 30,0 & 8,0 \\
\hline
\end{tabular}

Tablo 5. Bireylerin eğitim ve yaş smoflamasına göre kalsiyum alımlarna iliş̧kin istatistiksel tanımlama değerleri

\begin{tabular}{|c|c|c|c|c|c|c|c|}
\hline Enerji ve besin öğeleri & $\mathbf{n}$ & Ort. (SS) & $\mathrm{S} \overline{\mathbf{x}}$ & $\begin{array}{l}\text { Alt } \\
\text { sinir }\end{array}$ & $\begin{array}{c}\text { Üst } \\
\text { sinır }\end{array}$ & $t$ & $p$ \\
\hline \multicolumn{8}{|l|}{ İlkokul } \\
\hline Kent & 12 & $830,3(562,6)$ & 162,4 & 243 & 1873 & \multirow{2}{*}{1,55} & \multirow{2}{*}{0,1} \\
\hline Kirsal & 27 & $611,7(316,7)$ & 60,9 & 128 & 1485 & & \\
\hline \multicolumn{8}{|l|}{ Lise } \\
\hline Kent & 230 & $826,5(544,7)$ & 35,9 & 122 & 3657 & \multirow{2}{*}{2,97} & \multirow{2}{*}{$<0,001^{* * *}$} \\
\hline Kirsal & 68 & $648,7(394,3)$ & 47,8 & 120 & 2136 & & \\
\hline \multicolumn{8}{|l|}{ Üniversite } \\
\hline Kent & 56 & $776,9(425,7)$ & 37,8 & 206 & 2220 & \multirow{2}{*}{1,36} & \multirow{2}{*}{0,09} \\
\hline Kirsal & 5 & $511,0(268,6)$ & 61,2 & 286 & 820 & & \\
\hline \multicolumn{8}{|l|}{ Yüksek lisans ve doktora } \\
\hline Kent & 2 & $1065,0(394,6)$ & 279,0 & 786 & 1344 & \multirow{2}{*}{ - } & \multirow{2}{*}{-} \\
\hline Kirsal & - & - & - & - & - & & \\
\hline
\end{tabular}

Not: Ort. (SS) = Ortalama (Standart sapma), $\mathrm{S} \overline{\mathrm{x}}=$ Standart hata, $t=$ test değeri, $p=$ anlamlılık değeri $* p<0,05 * * p<0,01 * * * p<0,001$

diyet kalsiyumu ek kalsiyumdan daha iyi emildiği için kemik oluşumu üzerinde daha büyük bir etkiye sahip olduğu ileri sürülmekle birlikte konunun tam olarak açıklanması için daha fazla çalışmaya ihtiyaç duyulduğu vurgulanmaktadır (Li vd., 2018). Gerçekleştirilen bu araştırmada ise kentte yaşayan kadınların \%2,0'si kalsiyum ve $\mathrm{D}$ vitaminini ek olarak kullandığ 1 belirlenmiştir. İran'ın Tahran kentinde sağlık ocağına başvuran 18 yaş üstü 690 kadının \%15,9'unun kalsiyum ve $\mathrm{D}$ vitaminini ek olarak kullandıkları ortaya çıkmıştır (Najmabadi, 2010). Bahsedilen araştırmada bulunan oranın bizim araştırmamızdan yüksek olmasının nedeni, herhangi bir sağlık problemi nedeniyle sağlık ocağına başvuru yapan bireyler üzerinde yürütülmüş olması olabilir. Ayrıca bahsedilen araştırmadaki yaş ortalaması bu araştırmadakinden daha düşük olduğu için de oran farklılık göstermiş olabilir.

İran'ın illerinde beslenme alışkanlığı ve besin tüketim durumu ile ilgili 1983 yılından itibaren detaylı çalışmalar yapilmaktadır. İran'da 1983-2002 yılları arasında yapılan çalışmalara göre; enerji alımlarının ortalama \%17,0 arttığ ve günlük enerji alımının ortalama 2067 kkal'den 2108 
kkal'e yükseldiği saptanmıştır. Bu miktar 2012 yılında 2364 kkal olarak belirlenmiştir. Ülkede günlük alınan enerjinin \%67,0'sinin karbonhidratlardan, \%22,0'sinin yağlardan ve \%11,0’inin proteinlerden karşılandığ1 bulunmuştur (Bahadora vd., 2012). Erdebil ilinde 2008 yılında yapılan bir çalışmada ise enerji alımının RDA'ya göre daha fazla olduğu belirlenmiștir (Kalanteri vd, 2008). Araştırmamızda ise kentte ve kırsalda sırasıyla, enerjinin $\% 16,1$ ve $\% 15,6$ 's1 proteinden, $\% 60,8$ ve 64,7's1 karbonhidrattan, \%23,1 ve 19,7'si yağdan karşılandığı belirlenmiştir. Yağdan karşılanan enerjinin kentte ve kırsalda önerilen değerin altında olduğu ve proteinden karşılanan enerjinin önerilenden daha fazla olduğu ortaya çıkmıştır. Araştırmamız sonuçları yağ ve karbonhidrattan karşılanan enerji açısından Erdebil'de yapılan diğer araştırmaya benzerlik gösterirken, proteinden karşılanan enerji açısından farklılık göstermektedir. Yine Türkiye'de tıp öğrencileri üzerinde yapılan benzer bir araştırmada kadın öğrencilerin günlük ortalama enerji alımlarının önerilenin altında olduğu $(13,03 \pm 354,5)$ bulunmuştur. Bu enerjinin \%46,7'si karbonhidratlardan, \%16,6's1 proteinlerden ve \%36,7'si yağlardan karşılanmakta olduğu tespit edilmiştir (B1y1klı vd., 2018). Araştırmamız Türkiye'de yapılan bu çalışma ile enerji alımı ve proteinden karşılanan enerji açısından benzerlik göstermektedir. Ancak yağ ve karbonhidrat alımı açısından benzerlik bulunmamaktadır. $\mathrm{Bu}$ araştırmada yağ alım oranının çalışmamızdan daha yüksek, karbonhidrat alım oranının ise daha düşük tespit edildiği görülmektedir. Bu iki araştırma arasındaki farklılık Türkiye'deki araştırmanın sadece üniversite öğrencileri üzerinde yürütülmüş olması ve öğrencilerin fastfood tarz1 beslenmeyi daha fazla tercih ediyor olmasından kaynaklanmış olabilir.

Erdebil kırsalında yapılan bir araştırmaya göre

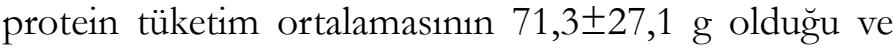
bunun RDA'ya göre fazla olduğu belirlenmiştir (Nameti vd., 2003). Yine Erdebil ilinin kirsal ve kentinde yaşayan menopoz döneminde olan kadınlar üzerinde yapılan bir çalışmada, kırsalda yaşayan kadınların enerji ve protein alımlarının kentte yaşayan kadınlara göre daha yüksek olduğu bulunmuş ve aralarındaki farklılığın istatistiksel açıdan anlamlı olduğu saptanmıştır $(\mathrm{p}<0,05)$ Nameti ve Naghizadeh Baghi, 2008). Çalışma sonuçlarımız kent ve kırsal karşılaştırması açısından bu araştırma ile farklılık göstermektedir. Farkın nedeni çalışmaların yaş grupları üzerinde gerçekleştirilmiş olması olabilir. Türkiye'de Gaziantep Üniversitesi'nde okuyan öğrencilerin beslenme durumunu saptamak için yapılan bir çalışmada, kadın öğrencilerin \%95,7'si protein alımlarının DRI önerilerinin sınırında olduğu saptanmış ve enerji alımının yetersiz olduğu belirtilmiştir (Sağır, 2019). Çalışmamızda ise bireylerin günlük ortalama tükettikleri protein miktarının kentte, kırsala göre daha yüksek olduğu ortaya çıkmıştır. Bu değer 18-30 yaş grubu için önerilen DRI değerlerinin kent ve kırsal için sirasiyla \%189,0 ve \%161,0’ine denk gelmektedir. Protein alımı açısından kentle kırsal arasındaki farklılık anlamlı bulunmuştur $(\mathrm{p}<0,001)$. Günlük protein alım miktarları DRI ile karşılaştırıldı̆̆ı zaman fazla tüketenlerin oranı, kentte $\% 73,7$, kırsalda ise $\% 71,0$ olarak belirlenmiştir. $\mathrm{Bu}$ yönüyle çalışma sonuçlarımız protein tüketimi açısından İan'da yapılan diğer araştırmalarla benzerlik gösterirken, Türkiye'de yapılan araştırma ile farklılık sergilemektedir. Bunun nedeni katılımcıların öğrenci olması, şehir ve kültür farklılıkları olması olabilir.

İran'da çalışan kadınlar üzerinde yapılan bir araştırmada kalsiyum alımı Dietary Reference Intake (DRI)'nın önerilerinden daha düşük bulunmuştur. Araştırmada kalsiyum tüketim miktarı günlük ortalama

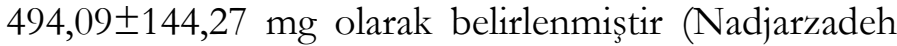
vd., 2016). Diğger bir çalışmada ise İran'da süt ve süt ürünleri tüketiminin önerilen miktarın \%25'inden daha az olduğu saptanmıştır. Ülkede kişi başına kalsiyum ihtiyacının \%35'i karşılanamamaktadır. İran'da süt ve süt ürünlerinin en çok tüketildiği ilde kişi başına düşen kalsiyum miktarı 221 gr iken süt ve süt ürünlerinin en az tüketildiği ilde kalsiyum miktarı 139 gr olarak saptanmıştır (Abdi vd., 2015). Çalışmamız sonucunda da hem kentte hem de kırsalda yaşayan kadınlarda kalsiyum alımı DRI değerlerine göre daha düşük tespit edilmiştir.

Araştırmamızda günlük ortalama kalsiyum alımının kentte kırsala göre daha çok olduğu belirtilmiştir. Ancak her iki yerde de kalsiyum alım miktarının önerilen değerlerin altında olduğu ortaya çıkmıştır. DRI'ye göre kalsiyumu yetersiz alanların oranı kentte $\% 50,3$, kırsalda ise \%63,0'dır. Yine kalsiyum alımı yönünden kentle kırsal arasındaki farklılık önemli bulunmuştur $(p<0,001)$. Erdebil kırsalında 19-50 yaş arası kadın ve erkekler üzerinde yapılan bir araştırmada, ortalama kalsiyum tüketiminin kadinlarda 460,7士199,9 mg olduğu saptanmıştır (Nameti vd., 2003). Erdebil ilinde kent ve kırsalda yaşayan menopoz döneminde olan kadınların üzerinde yapılan araştırmaya göre kırsaldaki kadınların kalsiyum alımının WHO'nun önerilerine göre daha fazla olduğu saptanmıştır (Nameti ve Naghizadeh Baghi, 2008). Türkiye'de üniversitede okuyan k1z öğrenciler üzerinde yapılan bir araştırmada, ortalama kalsiyum alımı 537,5 mg bulunmuştur. Bu değerin önerilen değerlerin altında olduğu saptanmıştır. Öğrencilerde süt ve ürünlerinin tüketiminin az olması kalsiyum alımının düşük olmasına neden olarak belirtilmiştir (Sağır, 2019). Yeni Zelanda ve İngiltere'de 15-28 yaş arasında olan kadınlar üzerinde bir çalışmada, kadınların \%15-20'sinde kalsiyum tüketiminin az olduğu saptanmıştır (Horwath vd, 2001). Türkiye'de, tıp öğrencilerinin üzerinde yapılan bir araştırmada öğrencilerin yarıdan fazlasının kalsiyum alımının yetersiz olduğu saptanmıştır (Biyıklı vd., 2018). Diğer bir çalışmada ise üniversiteli kadın öğrencilerin düzensiz beslendikleri için kalsiyum gibi besin öğelerini 
yetersiz aldıkları belirlenmiștir (Sağır, 2019). Meksika'da kent ve kırsalda yaşayan kadınların üzerinde yapılan bir araştırmada ortalama kalsiyum alımı kişi başına $495 \mathrm{mg}$ olarak belirlenmiştir. Kırsalda (546 mg/gün) yaşayan kadınların kentte (455 mg/gün) yaşayan kadınlara göre yaklaş1k $100 \mathrm{mg}$ daha fazla kalsiyum aldıkları belirlenmiștir (Filip vd., 2001) Kursalda ve kentte hipertansiyon problemi olan kadınların üzerinde yapılan bir çalışmada tüm kadınların diyetinde kalsiyum alımı önerilen değerin altında bulunmuştur (Suliburska vd., 2012).

Kadınların ortalama magnezyum alımlarının, kentte kırsala göre daha düşük olduğunu ortaya koyan bu çalışmada değerler DRI değerlerinin altındadır. Bunun nedeni kış mevsiminde yeşil yapraklı sebzelerin az tüketilmesi olabilir. Ayrıca başlıca besin kaynağı olan ekmek, İran'da daha çok rafine undan yapılmaktadır. Magnezyumun en iyi kaynakları sert kabuklu meyveler, kuru baklagiller, yeşil yapraklı sebzeler ve tam tahıl ürünleridir. Tahılların öz ve kepeğinin ayrılması magnezyum içeriğini azaltır (Aksoy, 2020). Kentte ve kırsalda yaşayanlar magnezyum alımı açısından karşılaştırıldığı zaman aralarındaki farklılık anlamlı bulunmamıştır ( $p>0,05)$. DRI'ya göre magnezyumu yetersiz alanlarin oran1, kentte \%83,7, k1rsalda ise \%78'dır. Erdebil kırsalında 19-50 yaş arası kadınlar ve erkekler üzerinde yapılan bir araştırmada, ortalama magnezyum tüketiminin kadinlarda 113,8 $\pm 87,3 \mathrm{mg}$ olduğu saptanmıştır (Nameti vd., 2003). Kır ve kentte hipertansiyon problemi olan kadınların üzerinde yapılan bir çalışmada tüm kadınların diyetinde magnezyum alımı önerilen değerlerin altında bulunmuştur. Kentte yaşayan kadınların magnezyum alımının kırsalda yaşayan kadınlara göre daha düşük olduğu ortaya çıkmıştır (Suliburska vd., 2012).

$\mathrm{Bu}$ çalışmada kadınların çinko alımı açısından kent ve kırsal bölgeler karşılaştırıldığında aralarındaki farklılık anlamlı bulunmamıstır ( $p>0,05)$. DRI'ya göre çinkoyu yetersiz alanların oranı, kentte $\% 68,1$, kırsalda ise \%62,0'dir. Çinkonun yeterli tüketimi kalsiyum emilimi için önemlidir. Çinko kalsiyumun bağırsaktan emilimini etkilemektedir (Aksoy, 2020). Çinko emilimini diyet ile alınan kalsiyum çok etkilememektedir ancak ek olarak kalsiyum alındığında, kalsiyum fitat içeren besinlerden çinkonun emilimini arttırabilir fakat yüksek dozda kalsiyum alımı çinko emilimini negatif yönde etkileyebilir. Yapılan bir araştırmada çinko tüketimi açısından kent ve kırsalda önerilen değerlerin üstünde bulunmuştur. Kırsalda yaşayan kadınlar kentte yaşayan kadınlardan daha fazla diyetlerinde çinko almaktadırlar (Suliburska vd., 2012). Türkiye'de öğrenciler üzerinde yapılan bir araştırmada kadın öğrencilerde çinkonun yeterli düzeyde tüketilmediği saptanmıştır (Sağır, 2019).

Fosfor alımının DRI değerlerine göre daha yüksek olması bu çalışmanın bulguları arasında yer almaktadır. Bunun yanında fosfor alımı açısından kentle kırsal arasındaki farklılık önemli bulunmamıştır. DRI değerlerine göre fosforu fazla tüketenlerin oranı kent ve kirsalda sirasiyla \%59,3 ve \% 51,0'dir. Ek olarak araştırmamızda Kalsiyum/Fosfor oranının kentte kırsala göre daha yüksek olduğu bulunmuştur. Fosfor gereksinimi günlük alınan kalsiyum kadardır. Doğal diyetin fosfor içeriği genelde kalsiyumdan yüksektir. Diyette etin çok olması fosfor alımını arttırırken, kalsiyum alımını azaltır. Diyette, kalsiyum ve fosforu eşit oranlarda bulunduran süt ile fosfordan çok kalsiyum içeren sebze ve meyvenin yeterince yer alması bu dengesizliği önler (Baysal, 2017). İran'ın kuzey doğu bölgesinde yapılan bir araştırmada kadınlarda kalsiyum/ fosfor oranı 0,66 olarak saptanmıştır. Kalsiyum alımı kadınlarda 864,2 mg/gün olduğu bulunmuştur ancak referanslara göre yetişkin kadınlar için $1000 \mathrm{mg}$ /gün kalsiyum önerilmektedir. Diyetle alınan fosfor miktarı kadınlarda $1307 \mathrm{mg} /$ gün bulunmuştur. Bu miktar önerilen miktardan (700 mg/gün) daha fazladır (Jafari vd., 2018).

Çalışmamızda kentteki kadınların \%94,7'sinin ve kırsaldaki kadınların \%72'sinin liseyi bitirmiş oldukları saptanmıştır. Bu durum kadınların büyük çoğunluğunun eğitim süresinin en az 12 yll olduğunu göstermektedir. Kentte ve kırsalda yaşayan ilkokul mezunu kadınların kalsiyum alımları açısından aralarındaki farkl11ı önemli bulunmazken, lise mezunu kadınların ortalama kalsiyum alımları açısından aralarındaki farklılık anlamlı bulunmuştur $(p<0,001)$. Doğurganlık çağında olan kent ve kırsalda yaşayan kadınların üzerinde yapılan bir araştırmada ise kadınların eğitim süresinin artmasına bağlı olarak beslenme bilgi düzeylerinin de arttığı bulunmuştur (Weerasekara vd., 2020). İran'da yapılan bir araştırmada üniversite öğrencilerinin \%87,5'inde beslenme bilgileri yeterli olarak belirlenmiştir. Kadın öğrencilerin ise \% 098,4 'ünde beslenme bilgi düzeyi yeterli olarak saptanmıştır (Al-hosseini vd., 2020). Yapılan araştırmalara göre yaş, cinsiyet, eğitim seviyesi ve meslek faktörlerinin beslenme bilgi düzeyi ile doğrudan ilişkisi olduğu saptanmıştır (Hoseini vd., 2019; Sharifnia vd., 2020). İran'ın merkez ve kirsal kesimlerinde yapilan bir diğer araştırmada, yine annelerin yaşı ve eğitim durumu ile enerji, kalsiyum ve vitamin alımlarının, bitkiselhayvansal besin tüketimlerinin çocukların beslenme alışkanlıklarıyla da doğrudan ilişkisi olduğu belirlenmiştir (Djazayery vd., 2010).

\section{Sonuç}

Sonuç olarak bu çalışmada kadınlarda kalsiyum, magnezyum ve çinko alımının önerilen seviyelerin altında olduğu görülmüştür. Kentte ve kırsalda yaşayan kadınlar arasında kalsiyum, enerji ve protein alımı açısından 
farklılıklar gözlenmiştir. Kentte ve kırsalda yaşayan lise mezunu kadınların ortalama kalsiyum alımları açısından aralarındaki farkın istatistiki olarak anlamlı oluşu eğitimin bu konudaki önemine işaret etmektedir. Kent ve kırsalda yaşayan kadınlar arasında gözlenen farkllıklar sosyoekonomik faktörlere bağlanabilir. Kalsiyum tüketiminin önerilen düzeyde alınması için süt gibi kalsiyumdan zengin besinlere erişimi kolaylaştırılması ile dengeli ve yeterli beslenme için sağlık politikalarının geliştirilmesi önem arz etmektedir.

\section{Kaynakça}

Abdi, F., Atarodi Kashani, Z., Mirmiran, P., ve Esteki, T. (2015). Surveyin global and Iranian food consumption patterns: A review of the literature. Journal of Fasa University of Medical Sciences, 5(2),159-167. http://journal.fums.ac.ir/article-1-677$\underline{\text { en.pdf }}$

Aksoy, M. (2020). Beslenme biyokimyası. Nobel Tip Kitabevi .

Al-hosseini, M. K., Khoshgoo, M., Taghizadeh, R., Tanha, K., ve Shidfar, F. (2020). Investigating the level of nutritional literacy and its accompanying factors in seminary students of Qom City in 2019. Qom University of Medical Sciences Journal, 14(1), 21-28. https://doi.org/10.29252/qums.14.1.21

Balk, E. M., Adam, G. P., Langberg, V. N., Earley, A., Clark, P., Ebeling, P., Mithal, A., Rizzoli, R., Zerbini, C. A. F., Pierroz, D. D., ve Dawson-Hughes, B. (2017). Global dietary calcium intake among adults: a systematic review. Osteporosis International, 28, 3315-3324. https://doi.org/10.1007/s00198017-4230-x

Bahadoran, Z., Mirmiran, P., Golzarand , M., Hosseini Esfehani, F., ve Azizi, F (2012). Fast food consumption in Iranian adults; dietary intake and xardiovascular risk factors: Tehran lipid and glucose Study. Archives of Iranian Medicine,15(6), 346-351. https://pubmed.ncbi.nlm.nih.gov/22642243/

Baysal, A. (2017). Beslenme. Hatipoğlu Yayınevi.

Bıyıklı, E. T., Bıyıklı, A. E., ve Çelik, B. (2018). Selçuk Üniversitesi Tıp Fakültesi öğrencilerinin enerji ve besin öğesi alımlarının değerlendirilmesi. Genel Tip Dergisi, 28(1). https://doi. org/10.15321/GenelTipDer.2018.168

Djazayery, A., Siassi, F., ve Kholdi, N. (2010). Food behavour and consumption patterns in rural areas of Sirjan, Iran. 2. Factors affecting food consumption, energy and nutrition intakes and food beliefs. Ecology of Food and Nutrition, 28(1-2), 119-130. https://doi.org/10.1080/03670244.1992.9991264

Filip, R. S., ve Zagórski, J. (2001). Bone mineral density and osteoporosis in rural and urban women. Epidemiological study of the Lublin region (Eastern Poland). Annals of Agricultural and Environmental Medicine, 8(2), 221-226. https:// pubmed.ncbi.nlm.nih.gov/11748880/

İan İstatistik Kurumu (2010). Ülkenin şehirlerinin nüfusunu tabmin etmek. Nüfus İstatistikleri, İşgücü ve Sayım Yayını. [Farsça] https://www.amar.org.ir/Portals/0/Files/abstract/1389/n baravord sh89.pdf
Geng, C., Shaikh, A. S., Han, W., Chen, D., Guo, Y., ve Jiang, P. (2019). Vitamin D and depression: Mechanisms, determination and application. Asia Pacific Journal of Clinical Nutrition, 28(4), 689-694. https://doi.org/10.6133/apicn.201912 28(4).0003

Hemmingway, A., O’Callaghan, K. M., Hennessy, Á., Hull, G. L. J., Cashman, K. D., ve Kiely, M. E. (2018). Interactions between Vitamin D status, calcium intake and parathyroid hormone concentrations in healthy white-skinned pregnant women at Northern Latitude. Nutrients, 10(7), 916. https:// doi.org/10.3390/nu10070916

Horwath, C., Parnell, W. R., Wilson, N. C. ve Russell D. G. (2001). Attaining optimal bone status: Lessons from the 1997 national nutrition survey. The New Zealand Medical Journal, 114(1128), 138-141. https:/ / pubmed.ncbi.nlm.nih.gov/11346163/

Hoseini, R., ve Hoseini, Z. (2019). Investigating nutritional literacy of male student athletes contributed in 2018 Iran university games. Journal of Health Literacy, 4(1), 53-59. https:// https:/ doi.org/10.22038/jhl.2019.40251.1053

Li, K., Wang, X. F., Li, D. Y., Chen, Y. C., Zhao, L.J., Liu, X. G., Guo, Y. F., Shen, J., Lin, X., Deng, J., Zhour, R. ve Deng, H. W. (2018). The good, the bad, and the ugly of calcium supplementation: A review of calcium intake on human health. Clinical Interventions in Aging, 13, 2443-2452. https:// doi.org/10.2147/CIA.S157523

Jafari Giv, Z., Avan, A., Hamidi, F., Tayefi, M., Khayyatzadeh, S. S., Javandoost, A., Nematy, M., Ferns, G. A., ve Mobarhan, M. G. (2018). Nutrients intake, and serum calcium and phosphorus levels: An evidence-based study. Journal of Clinical Laboratory Analysis, 32(2), e22235. https://doi.org/10.1002/jcla.22235

Kalanteri, N., ve Gaffarzade, M. (2008). Ülkenin hane halker gida tüketim sıkliğ ve beslenme durumu çalısmalar için kapsamli plan (Ylln ulusal raporu 2000-2008). Tarım Bakanlığı, Planlama ve Tarım Ekonomisi Çalışmaları Merkezi Yayını. [Farsça]

Nameti, A., Majidpoor, A., ve Saqgha, M. (2003). Dietary pattern among people of rural areas in Ardabil, 2000. Journal of Ardabil University of Medical Sciences, 3(2), 52-58. http://jarums. arums.ac.ir/article-1-533-en.html

Nemati, A., ve Naghizadeh Baghi, A. (2008). Assessment of nutritional status in post menopausal women of Ardebil, Iran. Journal of Biological Sciences, 8(1), 196-200. https://docsdrive. com/pdfs/ansinet/ibs/2008/196-200.pdf

Najmabadi, Sh., ve Nojomi, M. (2010). Nutritional Supplement Use among adults in different Areas of West Tehran. Iranian Journal of Endocrinology and Metabolism, 12(4), 365-375. http:// ijem.sbmu.ac.ir/article-1-822-en.html

Institute of Medicine. (1997). Dietary reference intakes for calcium, phosphorus, magnesium, vitamin $D$, and fluoride. The National Academies Press. https://doi.org/10.17226/5776

Institute of Medicine. (2001). Dietary reference intakes for vitamim $A, K$, arsenic, boron, chromium, copper, iodine, iron, manganese, molibdenium, nickel, silicon, vanadium and zinc. National Academies Press. https://doi.org/10.17226/10026

Institute of Medicine (2011). Overview of calcium. Ross, A. C Taylor, C. L., Yaktine, A.L., ve Del Valle, H. B. (Ed.) içinde, 
Dietary reference intakes for calcium and vitamin D (s. 35-75). National Academies Press. https://www.ncbi.nlm.nih.gov/ books/NBK56060/

Nadjarzadeh, A., Reshkouieh, Z., Helvayi, G., and Jaferi Nodoushan, R. (2016). Weight and nutritional intake status of carpet weavers in Yazd-1390. Journal of Occupational Medicine7(1), 6371. http://tkj.ssu.ac.ir/article-1-323-en.pdf

Pekcan, G. (2018). Beslenme durumunun saptanmas1. A. Baysal (Ed.) içinde, Diyet El Kitabı (s. 67-141). Hatiboğlu Yayınları.

Prentice, A. (2007). Elsie Widdowson lecture 2006 mining the depths: Metabolic insights into mineral nutrition: Symposium on 'Nutrition in early life: New horizons in a new century'. Proceedings of the Nutrition Society, 66(4), 512-521. doi:10.1017/ $\underline{\text { S0029665107005836 }}$

Pugliese, M. T., Blumberg, D. L., Hludzinski. J., ve Kay, S. (1998). Nutritional rickets in suburbia. Journal of the American College of Nutrition, 17(6), 637-641. https://doi.org/10.1080/07315724 .1998 .10718814

Robinson, C. H., Mueller, H., ve Weigley, S. (2020). Robinson's basic nutrition, N. Kholdi (Çev.). Cameeneger Yayınevi. [Farsça]

Sağır, G. Ş. (2019). Üniversite öğrencilerinin beslenme durumlarnm Akdeniz diyet kalite indeksi ile değerlendirilmesi [Yayımlanmamış yüksek lisans tezi]. Hasan Kalyoncu Üniversitesi, Beslenme ve Diyetetik Anabilim Dalı, Gaziantep. https://hdl.handle. net/20.500.11782/1850

Sharifnia, F., Ghaffari, M., Ramezankhani, A., ve Rakhshanderou, S. (2020). Socio-demographic predictors of health literacy among the elderly: A correlational study. Salamat-i Ijtimāi, 7(2), 116-126. http://doi.org/10.22037/ch.v7i2.22204

Suliburska, J., Bogdánski, P., Duda, G., Pupek-Musialik, D., Piątek, J., Żukiewicz-Sobczak, W., ve Krauss, H. (2012). An assessment of dietary intake and state of nutritional in hypertensive patients from rural and urban areas of Greater Poland. Annals of Agricultural and Environmental Medicine, 19(3), 339-343. https://pubmed.ncbi.nlm.nih.gov/23020021/

Tisdale, A. K., Agrón, E., Sunshine, S. B., Clemons, T. E., Ferris III, F. L., Chew, E. Y., ve Age-Related Eye Disease Study Research Group. (2019). Association of dietary and supplementary calcium intake with age-related macular degeneration. Age-related eye disease study report 39. JAMA Ophthalmology, 137(5), 543-550. https://doi.org/10.1001/ jamaophthalmol.2019.0292

Trumbo, P., Schlicker, S., Yates, A. A., ve Poos, M. (2002). Dietary reference intakes for energy, carbohydrate, fiber, fat, fatty acids, cholesterol, protein, and amino acids. Journal of the American Dietetic Association, 102(11), 1621-1630. https://doi. org/10.1016/s0002-8223(02)90346-9

USA, Canadian Standard Food Analyze. (1998). The Food Processor III. https://esha.com/products/food-processor/ [Bilgisayar yazılımı]

Wawrzyniak, N., ve Suliburska, J. (2021). Nutritional and health factors affecting the bioavailability of calcium: a narrative review. Nutrition Reviews, 79(12), 1307-1320. https://doi. org/10.1093/nutrit/nuaa138

Weaver, C. M., ve Peacock, M. (2019). Calcium. Advances in Nutrition, 10(3), 546-548. https://doi.org/10.1093/advances/nmy086

Weerasekara, P. C., Withanachch, C. R., Ginigaddara, G. A. S. , ve Ploeger, A. (2020). Food and nutrition-related knowledge, attitudes, and practices among reproductive-age women in marginalized areas in Sri Lanka. International Journal of Environmental Research and Public Health, 17(11), 3985. https:// doi.org/10.3390/ijerph17113985

Wrzosek, M., Woźniak, J., Kozioł-Kaczorek, D., ve Włodarek, D. (2019) The assessment of the supply of calcium and vitamin $\mathrm{D}$ in the diet of women regularly practicing sport. Journal of Osteoporosis, 9214926. https://doi.org/10.1155/2019/9214926 